\title{
SISTEM PENDUKUNG KEPUTUSAN PEMILIHAN BAHAN BAKU PRODUKSI DENGAN METODE WEIGHTED PRODUCT PADA PT. LUHAI INDUSTRI
}

\author{
Irma Yunita Ruhiawati ${ }^{1}$, Mochamad Yusuf Romdoni ${ }^{2}$ \\ Dosen Fakultas Ilmu Komputer Universitas Banten Jaya \\ Jl. Ciwaru Raya No. 73 Warung Pojok, Kota Serang - Banten \\ Email:Irma.yunita@unbaja.ac.id ${ }^{1}$,yusufromdoni@unbaja.ac.id ${ }^{2}$
}

\begin{abstract}
This study aims to be able to assist PT Luhai Industri Indonesia in processing data of new raw materials by making appropriate decisions with prices that are quite economical but with good enough quality, while the data processing techniques here use the decision support system method to determine adequate raw material production good and efficient. So not only is the information needed faster, the time needed to process the data will be faster. In the process of building a decision support system for the selection of raw materials for production using a system development method with a weighted product that uses a multiplication formula to link the rating of each attribute, where the rating must be raised first with the weight of the attribute concerned, in this study will use a method approach Waterfall in the development of the system from collecting data for user needs to the data to be processed into an attribute and weighting with the weighted product method in determining decisions on the final result of the software to be made, while the tools used in research to describe the flow of the system this is by using a structured method namely UML (Unfield Method Language) in describing the functional program model. This decision support system software will be built with Visual Studio 2010 programming language with a client server system so to adjust the system here will use MySQl as the database.
\end{abstract}

Keywords: Decision, Supports, System, Elections, Raw Materials

\section{PENDAHULUAN}

Persediaan bahan baku merupakan asset perusahaan yang berharga oleh karena itu persediaan harus dapat dikelola dengan baik. Pada perusahaan produksi yang biasanya banyak dihadapkan dengan masalah bahan baku, kelebihan atau kekurangan nilai kualitas bahan baku dapat mengakibatkan terganggunya kelancaran proses produksi serta kualitas hasil produksi itu sendiri.

PT. Luhai Industrial merupakan salah satu perusahaan yang bergerak di bidang pembuatan pentil sepeda motor dan mobil sebagai produk utama dengan jenis yang berbeda. Dalam melakukan suatu produksi, perusahaan melakukan persediaan bahan baku untuk menjalankan produksinya. Bahan baku yang digunakan dalam menghasilkan produk ini adalah karet alami, beberapa jennis valve, serta bahan 
pendukung lainnya seperti sparepart (corn. mur, ring, plate dan plastic cap). Saat ini pemesanan bahan baku hanya dilakukan bila terlihat persediaan yang dimiliki sudah hampir habis, dengan kata lain belum ada sistem untuk menentukankulitas dari pemesanan bahan baku yang berkualitas, akibatnya bahan baku yang kurang baik berefek pada penurunan kualitas hasil produksi dari yang kw 1 menjadi kw 2 dan ini mengakibatkan kerugian pula pada hasil penjualan produk tersebut. Perusahaan ini menggunakan sistem make to order dimana pembuatan produk-produknya berdasarkan order yang diterima. Perusahaan ini mempunyai gudang yang digunakan untuk menyimpan bahan baku yang disediakan serta menyimpan hasil produksi yang siap dipasarkan.

Sehingga dengan ini peneliti tertarik untuk melakukan penelitian tentang menentukan persediaan bahan baku prduksi di PT. Luhai Industrial. Pada penelitian kali ini peneliti coba menggunakan metode Weighted Product. Sehingga peneliti mengambil judul "Sistem Informasi Pendukung Keputusan Pemilihan Persediaan Bahan Baku Produksi Dengan Metode Weighted Product Pada PT. Luhai Industrial".

\section{METODE PENELITIAN}

Untuk membangun suatu sistem yang akan membantu dalam proses administrasi dan manajemen pada suatu perusahaan menggunakan Sistem Pendukung Keputusan dalam menentukan bahan baku yang tepat sesuai kebutuhan dan harga yang sesuai, hal ini dibutuhkan suatu teknik yang secara umum sudah terbukti dapat memberikan jalan dan juga solusi untuk membangun suatu sistem informasi menjadi terarah dan juga efektif yaitu menggunakan salah satu Metode Weighted Product yang akan digunakan dalam penelitian ini salah satunya adalah teknik pengumpulan data yang digunakan penulis dimana terdiri dari beberapa tahapan strategis sebagai berikut :

1. Studi literature (Library Research)

Tahapan ini meruapakan ssuatu teknik atau cara yang digunakan untuk menganalisis permasalahan dengan cara pengumpulan data melalui penulusuran kepustakaan yang berhubungan dengan sistem pendukung keputusan pemilihan bahan baku weighted product. 


\section{Studi Lapangan (Field Research)}

a) Interview

Ini meruapakan stau tahapan pada studi lapangan dengan cara pengumpulan data dengan wawancara atau mengajukan pertanyaan-pertanyaan secara langsung tentang masalah-masalah yang akan dibahas kepada user dan juga stake holder berdasarkan tujuan yang benar dan Objektif.

b) Observasi

Yaitu teknik pengumpulan data dengan cara mengamati secara langsung terhadap aktifitas yang dilakukan oleh pengendara dan juga pelaku pencurian sesuai dengan masalah yang akan dibahas.

3. Studi Kepustakaan

Tahapan terakhir dalam analisis masalah adalah melalui penelusuran tentang ttudi kepustakaan ddimana dalam tahapan ini pengembang melakukan pengumpulan bahan teoritis dalam membantu satu keputusan untuk membuat stategi diperancangan sistem salah satunya dengan cara membaca, mengutip dan membuat catatan yang bersumber pada bahan-bahan pustaka yang mendukung dan berkaitan dengan Sistem Pendukung Keputusan. Selanjutnya dengan cara mempelajari dan memahami sistem yang berhubungan dengan masalah yang akan dibahas dalam karya ilmiah ini. Hal ini dimaksudkan agar penulis memiliki landasan teori yang kuat dalam menarik kesimpulan.

Pada perancangan sistem aplikasi ini diimplementasikan dengan metode pemodelan secara visual menggunakan UML (Unified Modeling Language), jenis dari diagram UML yang dipakai yaitu :

1) Use-case Diagram

Diagram ini memperliahatkan himpunan use-case dan aktor-aktor yang berperan didalam sistem pendukung keputusan pemilihan bahan baku, dalam diagram ini penulis mengorganisasikan dan memodelkan setiap aktor yang berperan dalam sistem ini, diantaranya adalah aktor user penerima sebagai penerima file, aktor user pengirim dalam hal ini berperan sebagai pengirim file yang akan berhubungan dan mengatur settingan file yang akan dibagikan, serta aktor sebagai administrator dalam hal ini administrator berperan penting dalam 
mengelola infrastruktur cloud storage dan pemantauan, seperti manage user, manage storage security dan manage sharing folder.

2) Activity Diagram

Diagram ini memperlihatkan aliran dari suatu aktivitas ke aktivitas lainnya dalam suatu sistem, disini penulis akan menguraikan aktivitas yang dilakukan user pada saat upload data hingga mengirimkan lampiran yang berupa link download melalui media e-mail kepada rekan bisnis.

\section{3) Sequence Diagram}

Diagram ini sama halnya dengan activity Diagram, namun dalam sequence Diagram lebih menekankan pada pengiriman pesan dalam suatu waktu tertentu.

\section{Metodologi Pengembangan Sistem}

Sedangkan Metodologi pengembangan yang penulis gunakan pada aplikasi ini adalah menggunakan metodologi pengembangan model prototype. merupakan salah satu metode pengembangan perangat lunak yang banyak digunakan. Dengan metode prototyping ini pengembang dan pelanggan dapat saling berinteraksi selama proses pembuatan sistem. Sering terjadi seorang pelanggan hanya mendefinisikan secara umum apa yang dikehendakinya tanpa menyebutkan secaradetail output apa saja yang dibutuhkan, pemrosesan dan data-data apa saja yang dibutuhkan. Sebaliknya disisi pengembang kurang memperhatikan efesiensi algoritma, kemampuan sistem operasi dan interface yang menghubungkan manusia dan komputer.

Untuk mengatasi ketidakserasian antara pelanggan dan pengembang maka harus dibutuhkan kerjasama yang baik diantara keduanya sehingga pengembang akan mengetahui dengan benar apa yang diinginkan pelanggan dengan tidak mengesampingkan segi-segi teknis dan pelanggan akan mengetahui proses-proses dalam menyelesaikan sistem yang diinginkan. Dengan demikian akan menghasilkan sistem sesuai dengan jadwal waktu penyelesaian yang telah ditentukan.

Kunci agar model prototype ini berhasil dengan baik adalah dengan mendefinisikan aturan-aturan main pada saat awal, yaitu pelanggan dan pengembang harus setuju bahwa prototype dibangun untuk mendefinisikan kebutuhan. Prototype akan dihilangkan sebagian atau seluruhnya dan perangkat lunak aktual direkayasa dengan kualitas dan implementasi yang sudah ditentukan. 
Pada model prototyping kadang-kadang klien hanya memberikan beberapa kebutuhan umum software tanpa detil input, proses atau detil output. Di lain waktu mungkin dimana tim pembangun (developer) tidak yakin terhadap efisiensi dari algoritma yang digunakan, tingkat adaptasi terhadap sistem operasi atau rancangan form user interface. Ketika situasi seperti ini terjadi model prototyping sangat membantu proses pembangunan software. Proses pada model prototyping bisa dijelaskan sebagai berikut:

a. Pengumpulan kebutuhan: developer dan client bertemu dan menentukan tujuan umum, kebutuhan yang diketahui dan gambaran bagian-bagian yang akan dibutuhkan berikutnya. Detil kebutuhan mungkin tidak dibicarakan disini, pada awal pengumpulan kebutuhan

b. Perancangan : perancangan dilakukan cepat dan rancangan mewakili semua aspek software yang diketahui, dan rancangan ini menjadi dasar pembuatan prototype.

c. Evaluasi prototype: klien mengevaluasi prototype yang dibuat dan digunakan untuk memperjelas kebutuhan software.

Perulangan ketiga proses ini terus berlangsung hingga semua kebutuhan terpenuhi.Prototype-prototype dibuat untuk memuaskan kebutuhan klien dan untuk memahami kebutuhan klien lebih baik. Prototype yang dibuat dapat dimanfaatkan kembali untuk membangun software lebih cepat, namun tidak semua prototype bisa dimanfaatkan.Sekalipun prototype memudahkan komunikasi antar developer dan klien, membuat klien mendapat gambaran awal dari prototype. Adapum tahapantahapan dalam Prototyping adalah sebagai berikut:

a. Pengumpulan Kebutuhan

Pelanggan dan pengembang bersama-sama mendefinisikan format seluruh perangkat lunak, mengidentifikasikan semua kebutuhan, dan garis besar sistem yangakan dibuat.

b. Membangun Prototyping

Membangun prototyping dengan membuat perancangan sementara yang berfokus pada penyajian kepada pelanggan (misalnya dengan membuat input dan format output).

c. Evaluasi Prototyping 
Evaluasi ini dilakukan oleh pelanggan apakah prototyping yang sudah dibangun sudah sesuai dengan keinginann pelanggan. Jika sudah sesuai maka langkah 4 akan diambil. Jika tidak prototyping direvisi dengan mengulangi langkah 1, 2 dan 3 .

d. Mengkodekan sistem

Dalam tahap ini prototyping yang sudah di sepakati diterjemahkan ke dalam bahasa pemrograman yang sesuai.

e. Menguji Sistem

Setelah sistem sudah menjadi suatu perangkat lunak yang siap pakai, harus dites dahulu sebelum digunakan. Pengujian ini dilakukan dengan White Box, Black Box, Basis Path, pengujian arsitektur dan lain-lain.

f. Evaluasi Sistem

Pelanggan mengevaluasi apakah sistem yang sudah jadi sudah sesuai denganyang diharapkan. Jika ya, langkah 7 dilakukan; jika tidak, ulangi langkah 4 dan 5.

g. Menggunakan Sistem

Perangkat lunak yang telah diuji dan diterima pelanggan siap untuk digunakan.

\section{LANDASAN TEORI DAN LITERATURE REVIEW}

\section{Landasan Teori}

\subsection{Definisi SPK}

Beberapa sumber menjelasakan tentang definisi dari Sistem Pendukung Keputusan salah satunya adalah pendapat dari Kusrini (2007:7), keputusan merupakan kegiatan memilih suatu strategi atau tindakan dalam pemecahan masalah tersebut. Tindakan memilih strategi atau aksi yang diyakini manager akan memberikan solusi terbaik atas sesuatu itu disebut pengambilan keputusan.

Dalam buku Mallach (2000:37) yang berjudul Decision Support and Data Warehouse Systems disebutkan "a decision is reasoned choice among alternatives" yang jika diterjemahkan akan bermakna sebuah keputusan adalah pilihan di antara banyak alternatif.

Disebutkan puladalam buku yang sama "Making decision is part of the boarder subject of problem solving. Problem solving is the overall process of closing the gap between reality and a more desirabel situation. To solve 
problem, we must first realize that the problem, the gap, exists".

Jika diterjemahkan akan menjadi "Membuat keputusan adalah bagian dari subjek pemecahan masalah yang lebih luas. Memecahkan masalah adalah proses keseluruhan dari menutup celah antara realita dengan situasi yang lebih diinginkan. Untuk memecahakan masalah, terlebih dahulu harus menyadari bahwa masalah, celah memang ada".

Gambar 1 menunjukan bagaimana semua saling berhubungan satu sama lain dalam konteks keputusan.

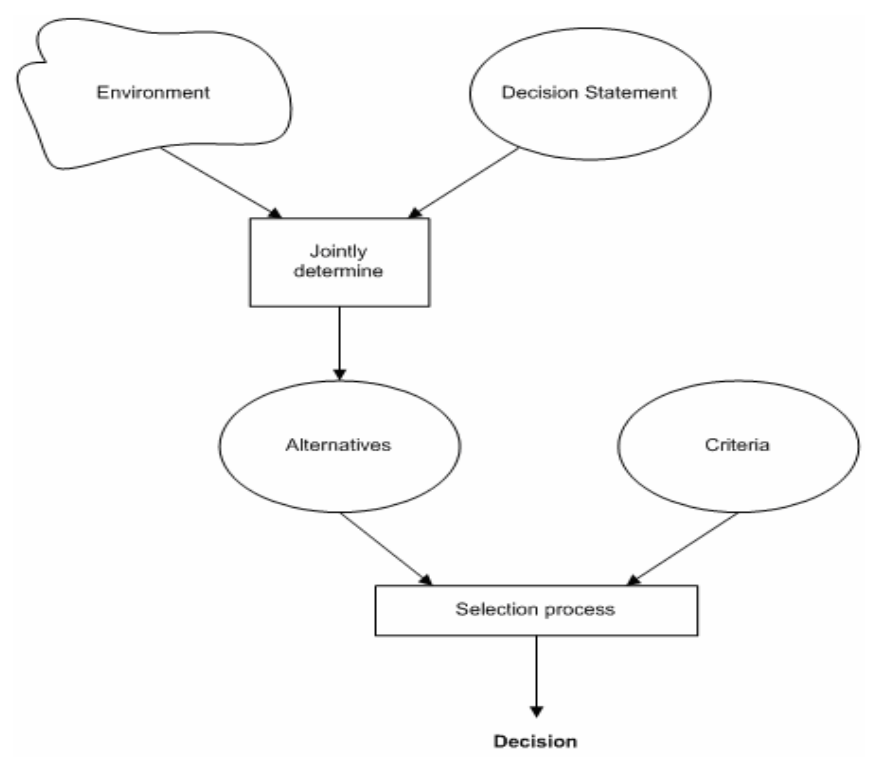

Gambar 1. Relationship Among Decision Statement, Alternatives, and Criteria Sumber: Mallach (2000, p38)

\subsection{Konsep Dasar Sistem}

Terdapat empat pendapat yang mendefinisikan pengertian masingmasing menekankan pada elemen/komponen sistem dan yang menekankan pada prosedurnya. Berikut kelima pendapat tersebut :

Menurut Richardus Eko Indrajit (2002:2) pendefinisian sistem mengandung arti "kumpulan dari komponen-komponen yang memiliki unsur keterkaitan antara yang satu dan lainnya".

H. M Jogiyanto (2005:3) mendefinisikan bahwa informasi adalah: "Data yang telah diletakkan dalam konteks yang lebih berarti dan berguna yang dikomunikasikan kepada penerima untuk digunakan didalam pembuatan keputusan". 
"Data yang telah diletakkan dalam konteks yang lebih berarti dan berguna yang dikomunikasikan kepada penerima untuk digunakan didalam pembuatan keputusan”.(H. M Jogiyanto, 2009:3)

George H. Bodnar (2006:30) juga mengungkapkan: "suatu sistem adalah kumpulan dari elemen - elemen yang menimbulkan hubungan satu dengan yang lainnya".

Dari beberapa definisi diatas dapat disimpulkan bahwa sistem adalah suatu komponen - komponen atau elemen - elemen yang saling berkaitan membentuk satu kesatuan dan menuju satu tujuan bersama.

Dari seluruh kelompok definisi diatas dapat disimpulkan bahwa seluruh definisi ini adalah benar dan tidak bertentangan, yang berbeda adalah cara pendekatannya, yaitu dengan pendekatan sistem yang lebih menekankan pada komponen akan lebih mudah dalam mempelajari suatu sistem untuk tujuan analisis dan perancangan.

Menurut Kenneth E. Kendall dan Julie E, (2010:3) Sistem Informasi Manajemen adalah "Sistem informasi yang sudah terkomputerisasi yang bekerja karena adanya interaksi antara manusia dan komputer".

Menurut Burch dan Grundnitski pada buku Analisa \& Sistem Informasi pendekatan terstruktur teori dan praktek aplikasi bisnis H.M Jogiyanto (2005:3) mendefinisikan informasi adalah : "Data yang telah diletakkan dalam konteks yang lebih berarti dan berguna yang di komunikasikan kepada penerima untuk digunakan didalam pembuatan keputusan”.

“informasi adalah kenyataan yang tampak maupun yang tidak tampak yang tersedia untuk mengurangi ketidakpastian tentang beberapa keadaan atau kejadian" (Henry C. Lucas, 1993).

Menurut Kursini (2007:7) Informasi adalah data yang sudah diolah menjadi sebuah bentuk yang berarti bagi pengguna, yang bermanfaat dalam pengambilan keputusan.

Jadi informasi dapat disimpulkan sebagai kumpulan fakta atau kenyataan yang mempunyai nilai untuk kemudian diolah menjadi bentuk yang lebih berguna dan bermanfaat bagi penerimanya untuk membuat keputusan. 


\section{Literature Review}

Banyak penelitian yang sebelumnya (literature review) dilakukan mengenai pembahasan tentang sistem informasi digital arsip yang sudah dikembangkan dilembaga-lembaga pemerintahan dan juga perusahaan. Dalam melakukan pengembangan sistem informasi digital arsip ini perlu dilakukan studi pustaka untuk dijadikan sebagai bahan acuan untuk memperkuat hasil penelitian dengan cara mengindentifikasikan metode yang pernah dilakukan, mengembangkan penelitian sebelumnya yang memiliki korelasi yang seimbang dengan sistem arsip digital. Beberapa literature review yang didapakan diantaranya adalah sebagai berikut :

1. Shiddiq Fahriadi Seban (2013) : "Sistem pendukung keputusan penentuan lokasi kantor bank indonesia gorontalo menggunakan metode weighted product"

Bank Indonesia adalah Bank Sentral Republik Indonesia. Kantor Bank Indonesia Gorontalo resmi berdiri pada tanggal 15 Desember 2008 dengan wilayah kerja meliputi Provinsi Gorontalo. Berdasarkan PDG no. 10/5/PDG/2008 tanggal 28 Agustus 2008 dan SE INTERN no. 10/71/INTERN tanggal 1 Desember 2008, KBI Gorontalo melaksanakan fungsi terbatas bidang ekonomi moneter kemudian akan menjalankan fungsi penuh secara bertahap sesuai dengan perencanaan dan kesiapan pemenuhan sarana, prasarana dan sumber daya Pada saat ini Kantor Bank Indonesia Gorontalo menjalankan fungsi ekonomi moneter, fungsi perbankan dan manajemen intern, namun dalam hal pelaksanaan sistem pembayaran masih belum dilaksanakan. Ke depan Bank Indonesia Gorontalo akan menjalankan fungsinya secara penuh dengan artian akan menjalankan fungsi sistem pembayaran. Namun kondisi tersebut masih terkendala terkait ketersediaan Gedung Kantor yang kurang representatif. Bank Indonesia melalui Direktorat Logistik dan Pengamanan (DLP) bekerjasama dengan Kantor Bank Indonesia Gorontalo saat ini berupaya menelaah dan menganalisis penetuan lokasi gedung kantor yang representative. Berdasarkan masalah diatas, upaya untuk membangun Sistem Pendukung Keputusan atau Decision Support System menjadi salah satu faktor yang penting untuk dilaksanakan sehingga dapat membantu pihak manajemen Bank Indonesia dalam penentuan lokasi 
Gedung Kantor. Dalam penelitian berikut sistem pendukung keputusan yang akan diaplikasikan adalah Metode Weighted Product, dengan sistem ini diharapkan dapat mengatasi masalah - masalah diatas.

2. Muh. Artanti Rim Saulana Manik (2012) "Penerapan Metode Weighted Product Dalam Sistem Pendukung Keputusan Seleksi Penerimaan Beras Untuk Masyarakat Miskin"

Masalah kemiskinan nerupakan salah satu persoalan mendasar yang menjadi pusat perhatian pemerintah dinegara manapun. Program Pemerintah yang digunakan untuk menanggulangi kemiskinan salah satunya adalah Raskin / Beras untuk masyarakat miskin yang diselenggarakan oleh BULOG. Dalam penentuan pemberian beras (raskin) yang berhak mendapatkan bantuan atau tidak. Tujuan penelitian ini adalah membuat sebuah sistem pendukung keputusan untuk menentukan penerima bantuan beras miskin di Kelurahan Tambak Aji Ngaliyan Semarang. Subjek penelitian ini adalah sistem informasi penentuan peneriman beras miskin dengan mengimplementasikan metode Weighted Product (WP). Dan penelitian ini menggunakan model waterfall yang meliputi analisa kebutuhan sistem, design atau perancangan, coding, testing, implelemtasi, serta pemeliharaan.

Sistem Pendukung Keputusan dibangun dengan menggunakan bahasa pemrograman PHP menggunakan database MySql. Hasil penelitian ini berupa implementasi metode Weighted Product untuk penentuan warga penerima beras msikin di Kelurahan tambak aji yang telah melalui pengujian black box. Penelitian dilakukan dengan mencari nilai bobot untuk setiap atribut, kemudian dilakukan proses perankingan yang akan menentukan alternatif yang optimal, yaitu calon penerima beras miskin. Berdasarkan pengujian yang dilakukan,sistem yang dibuat mampu memberikan hasil yang baik sesuai dengan perhitungan yang digunakan, membantu mempercepat dalam penyeleksian penerima beras miskin di kelurahan Tambakaji Semarang, dan juga sistem dapat megurangi kesalahan dalam menentukan calon penerima beras miskin.

3. Alfi Tri Ariani. “Analisis Metode Penilaian Persediaan Bahan Bakar Minyak Pada PT. Pertamina (Persero) Terminal BBM di alikpapan”. 
Barang-barang dagang dimiliki perusahan dengan besar maupun kecil, pada umumnya ditetapkan istilah sebagai persediaan barang dagang, bila mana barang-barang tersebut diperoleh dalam suatu kondisi untuk dijual kembali. Sedangkan istilah persediaan untuk perusahaan manufaktur adalah bahan baku, barang dalam proses dan barang jadi. Bagi perusahan dagang dan perusahan manufaktur, salah satu aset yang penting adalah persediaan. Dimana dalam perusahan ini jumlah persediaan tersebut sangat material, disamping itu transaksi yang berhubungan dengan persediaan tersebut sangat material. Persediaan dalam perusahaan mempunyai pengaruh terhadap penyajian laporan keuangan. Hal ini karena persediaan sangat mempengaruhi perhuitungan harga pokok. Kesalahan dalam penilaian, pengukuran dan penyajian persediaan akan mengakibatkan pada kesalahan pencatatan harga pokok penjualan dan akhirnya akan menghasilkan informasi yang salah pula terhadap pelaporan laba-rugi dan neraca perusahan. Persediaan merupakan aset penting baik jumlah maupun peranannya dalam perusahan. Dengan mengetahui besarnya persediaan yang tepat, maka pihak perusahaan akan memperoleh dasar yang cukup guna menunjang laporan keuangan yang layak dan wajar. Kondisi seperti ini disebabkan karena penentuan besarnya persediaan yang tepat maka dengan sendirinya perhitungan harga pokok penjualan akan tepat pula.

Salah satu faktor yang dapat mempengaruhi kebutuhan perusahaan akan modal kerja adalah peraturan persediaan, makin banyak persediaan dijual dan diganti kembali, maka makin kecil modal yang diperlukan. Pengendalian persediaan yang efektif diperlukan untuk memelihara jumlah, jenis dan kualitas barang yang sesuai dan untuk investasi dalam persediaan. Lebih cepat persediaan berputar, maka lebih sedikit resiko kerugian jika persediaan itu turun nilainya atau jika terjadi perubahan dalam permintaan. Untuk memberikan informasi perencanaan dan pengawasan efisiensi dalam pengambilan keputusan pada manajemen diperlukan suatu alat informasi. Sehubungan dengan hal tersebut pihak manajemen perlu mengambil kebijakan dan pengendalian secara efektif untuk memperoleh apa tujuan dari perusahaan agar berkembang dari tahun ke tahun dapat semakin meningkat. Karena itu perhitungan harga pokok penjualan akan membantu pihak 
perusahan dan manajemen perusahan dalam menyusun rencanadan menentukan tindakan yang dinyatakan secara kuantitatif mengenai apa yang diinginkan dan dapat dicapai oleh perusahan pada masa mendatang dan rencana-rencana yang relevan. Penilaian persediaan itu sendiri adalah penentuan nilai persediaan yang tercantum dalam neraca. Persediaan akhir bisa dihitung harga pokoknya dengan menggunakan beberapa penentuan harga pokok persediaan akhir, tetapi nilai ini sendiri tidak selalu nampak dalam neraca, jumlah yang dicantumkan dalam neraca tergantung pada metode penilaian. Penilaian persediaan menurut perusahan adalah kegiatan penilaian persediaan yang dilakukan pada akhir periode, melainkan pada setiap transaksi pembelian. Karena harga rata-rata pada sistem ini berubahubah (bergerak) setiap terjadi transaksi pembelian dengan harga perolehan perunit yang tidak sama dengan harga perolehan rata-rata per unit sebelumnya.

\section{HASIL DAN PEMBAHASAN}

\section{Identifikasi Masalah}

Dari gambaran yang telah dikemukakan di atas, maka dapat dirumuskan beberapa permasalahan pokok yang menjadi acuan didalam mengembangkan sistem tersebut dianataranya adalah sebagai berikut :

1) Sulitnya memilih bahan baku yang berkualitas dan efisien serta memenuhi standar yang diharapkan untuk kebutuhan produksi.

2) Sistem yang ada belum dapat diandalkan sebagai abahn kontrol untuk memberikan informasi yang cepat serta akurat mengenai bahan baku yang diterima dari berbagai pemasok sehingga menyulitkan para pegawai didalam menentukan bahan baku yang akan dipilih.

\section{Analisis Sistem}

\section{a. Analisa Batasan dan Kebutuhan}

Agar Penelitian ini dapat dilakukan lebih fokus mengingat luasnya permasalahan yang ada pada suatu perusahaan maka maka dipandang permasalahan penelitian yang diangkat perlu dibatasi variabelnya, Oleh karena itu pada penelitian ini ruang lingkup yang akan dibahas hanya berkaitan dengan: 
1) Pemanfaatan utama server cloud storage adalah untuk layanan pertukaran informasi jarak jauh dengan rekan bisnis.

2) Sistem keamanan dalam server tidak dibahas dalam penelitian ini dan hanya membahas desain sistem pada server seperti layanan yang diberikan oleh server.

3) Penelitian ini dititik beratkan pada konfigurasi cloud storage menggunakan Owncloud dan perangkat lunak open source linux ubuntu server.

\section{b. Analisis Kebutuhan}

\section{Perangkat Lunak yang Digunakan}

Perangkat lunak yang digunakan dalam pembuatan cloud storage ini adalah :

1. Windows $7 / 10$, sebagai sistem operasi untuk melayani kebutuhan skala server.

2. Visual Studio 2008/2010/2012 sebagai software editor untuk mendesain interface serta logika sistem pendukung keputusan.

3. Xampp versi terbaru sebagai editor untuk mengolah database MySql dan web server.

4. Browser google chrome Version 74.0.3729.157

\section{Perangkat keras yang digunakan}

Perangkat keras yang digunakan dalam pembuatan SPK Pemilihan Bahan Baku produksi ini adalah Notebook atau PC dengan Minimum spesifikasi :

a. Processor Intel Pentium DualCore atau yang setingkat,

b. RAM minimal $2 \mathrm{~GB}$,

c. Hard Disk $250 \mathrm{~GB}$,

d. Lan Card Realtek RTL 8139 Family PCI Past Ethernet NIC

e. VGA Card minimal $512 \mathrm{MB}$

f. Monitor,Mouse, Keyboard, dan CD ROM Drive 


\section{Perancangan Sistem}

\section{a) UML}

1) Use Case Diagram

Use case mendeskripsikan sebuah interaksi antara satu atau lebih aktor dengan sistem yang akan dibuat. Diagram use case digunakan untuk mengetahui fungsi apa saja yang ada di dalam sebuah sistem dan siapa saja yang berhak menggunakan fungsi-fungsi tersebut.

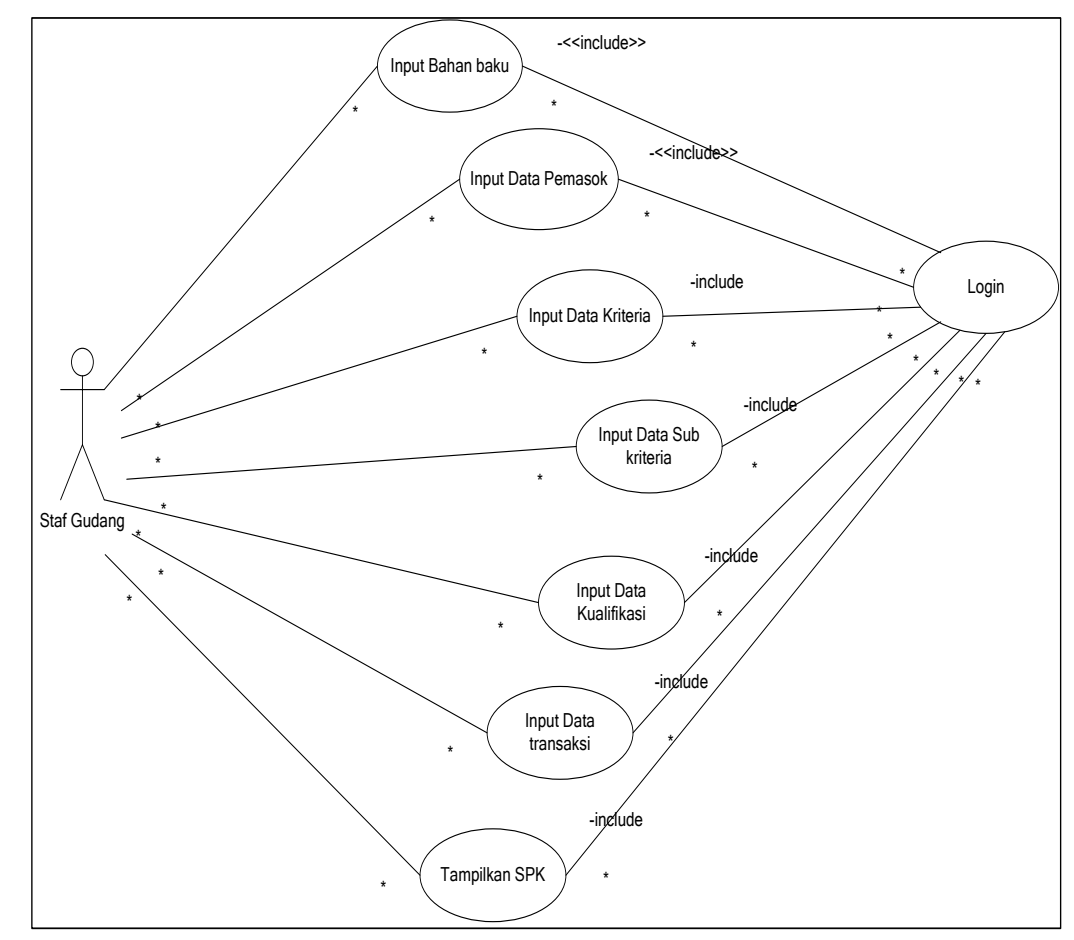

\section{Gambar 2. Use Case Diagram}

Pada gambar Use Case di atas menunjukan bahwa untuk dapat mengoperasikan aplikasi tersebut Staff Gudang yang berpesan sebagai aktor harus melalui login terlebih dahulu, kemudian terdapat input data bahan baku, pemasok dan kriteria yang menjadi data master, sedangkan input data sub kriteria, input data klasifikasi adalah bagian daripada proses transaksi yang berkaitan langsung pada proses transaksi untuk menentukan bahan baku yang sesuai dengan kriteria yang telah ditetapkan oleh perusahaan. Hasil dari proses tersebut akan ditampilkan melalui form tampil SPK dimana informasi yang ditampilkan merupakan data yang 
telah matang untuk dijadikan bahan masukan oleh perusahaan khususnya bidang persediaan bahan baku.

Berikut ini adalah sampel dari activity diagram diagram yang menggambarkan aliran kerja atau aktivitas dari sebuah sistem atau proses bisnis dari Sistem Pendukung Keputusan Pemilihan Bahan Baku.

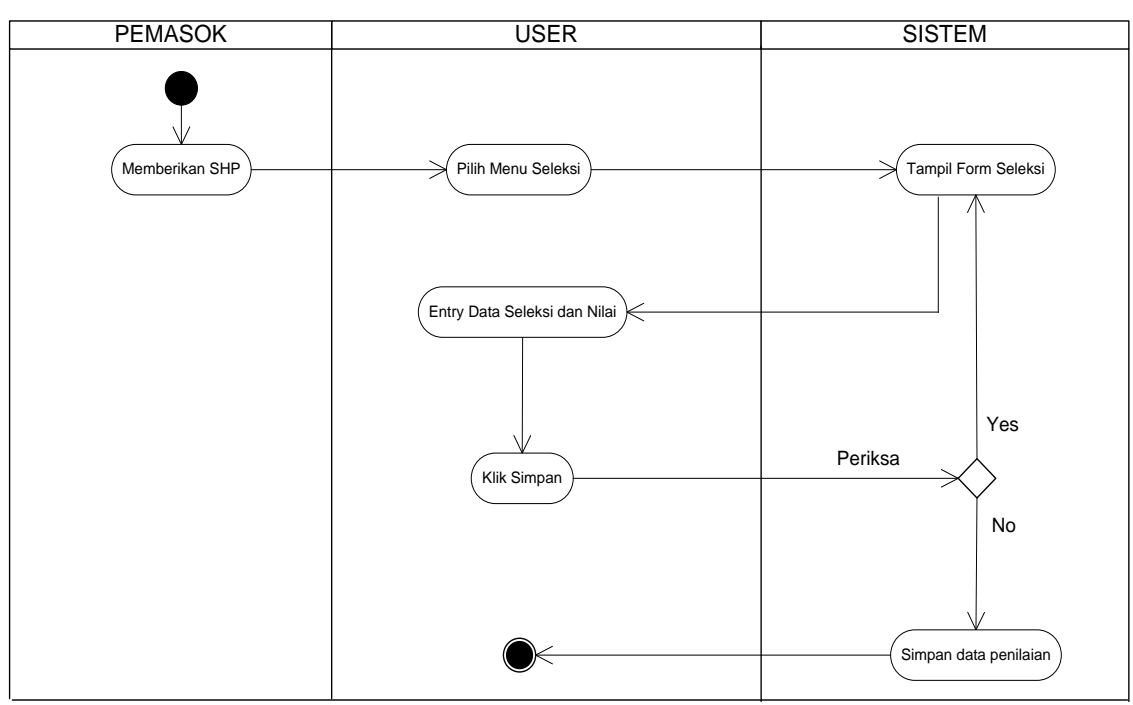

Gambar 3. Activity Diagram

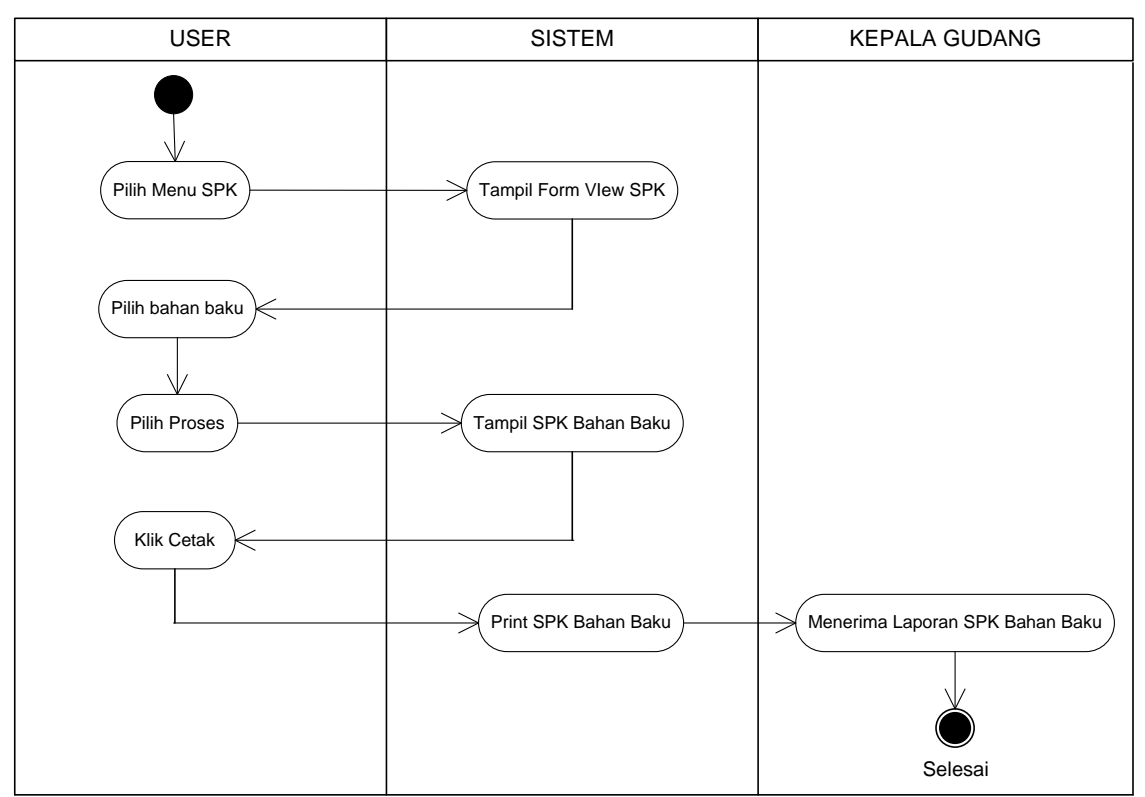

Gambar 4. Activity Diagram View 


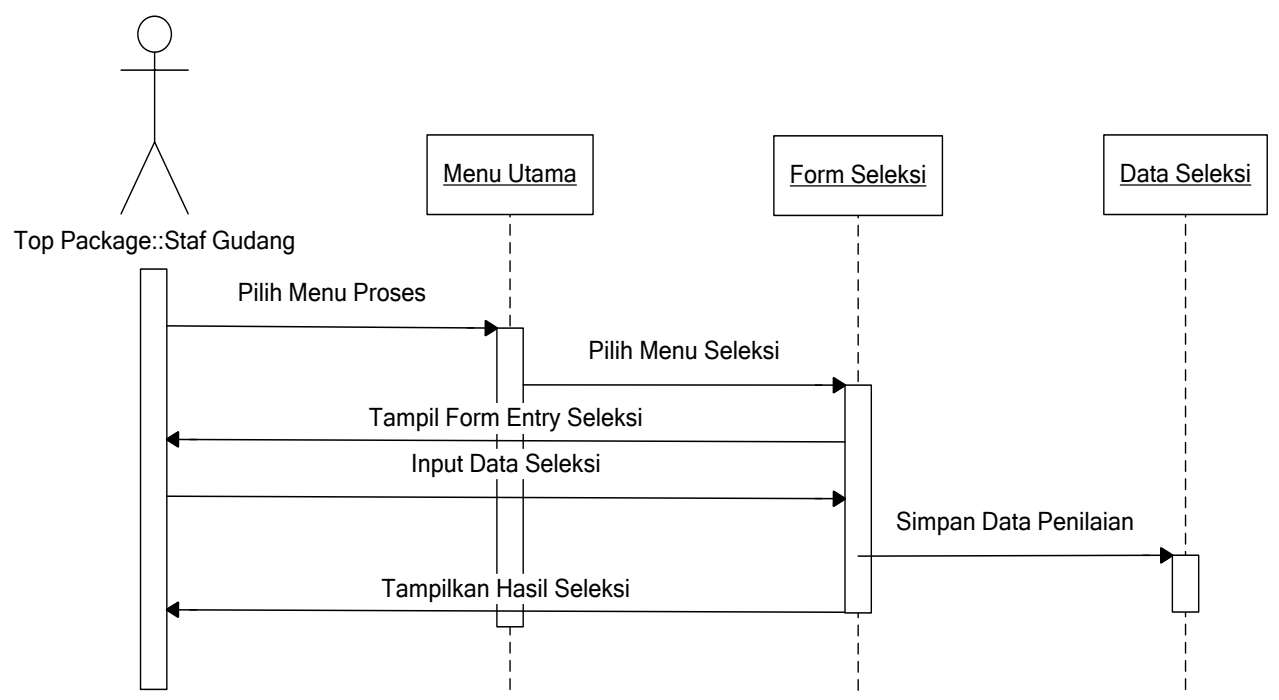

Gambar 5. Sequence Diagram

\section{b) Tampilan Program}

Berikut ini akan ditampilkan sampel dari tampilan program dari Sistem Pendukung Keputusan Pemilihan Bahan Baku dengan metode Weighted Product salah satunya adalah proses penghitungan pada form transaksi.

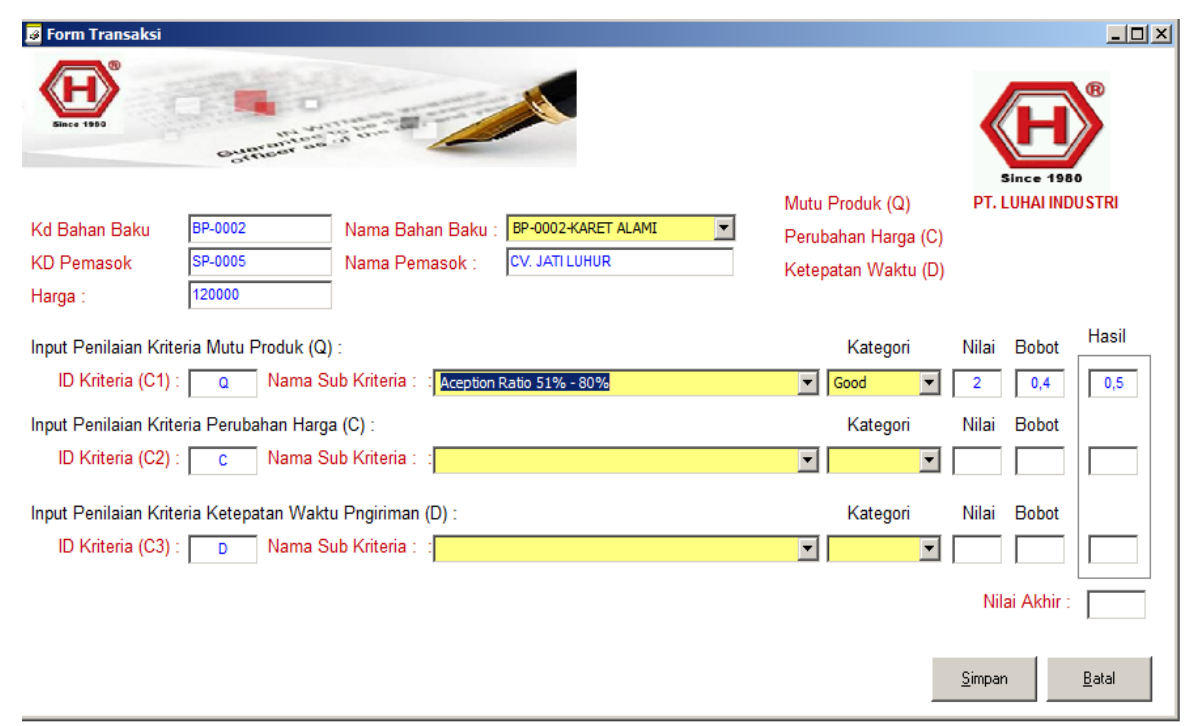

Gambar 6. Form Transaksi Pengitungan Kriteria 


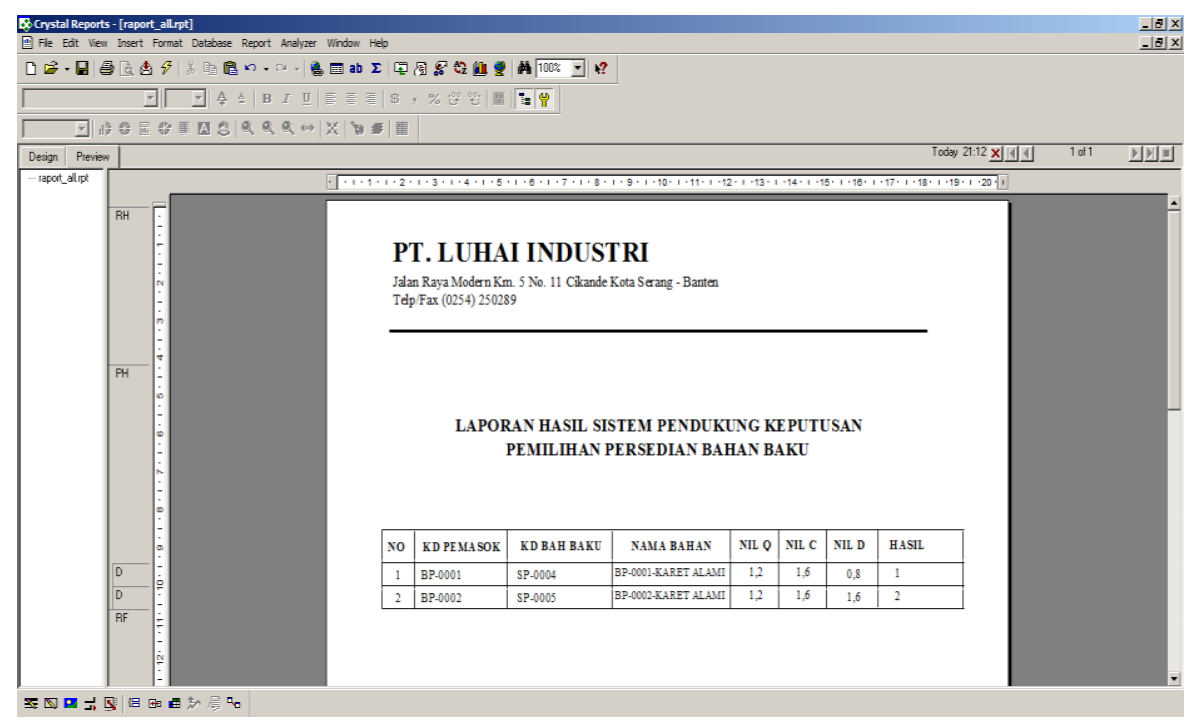

Gambar 7. Hasil Pengitungan Kriteria

\section{KESIMPULAN}

Setelah melakukan analisis, perancangan, dan pengujian, maka dapat diperoleh kesimpulan sebagai berikut :

1. Dengan adanya Sistem Pendukung Keputusan Pemilihan Bahan Baku dengan Metode Weighted Product yang dibangun dapat membantu PT. Luhai Industri sebagai gambaran bagi pengambilan keputusan perusahaan dalam rangka mendapatkan supplier terbaik.

2. Sistem yang dibangun dapat mempercepat proses pemilihan bahan baku dari pemasok.

3. Sistem yang dibangun mampu menangani pengolahan dan pengelolaan Data dengan cepat dan efisien.

\section{DAFTAR PUSTAKA}

Al-Bahra. 2005. Analisis dan Desain Sistem Informasi. Yogyakarta: Graha Ilmu.

Alfi Tri Ariani. “Analisis Metode Penilaian Persediaan Bahan Bakar Minyak Pada PT. Pertamina (Persero) Terminal BBM di alikpapan”. E-journal Universitas Mulawarman. Samarinda

Bodnar, George H and William S Hopwood, 2006. Sistem Informasi Akuntansi, Yogyakarta: Andi.

Henry C. Lucas Jr, 1993, Analisis Desain Dan Implementasi, Erlangga, Jakarta 
Indrajit, Richardus Eko, 2002, Konsep \& Aplikasi e-Business, Andi, Yogyakarta

Jogiyanto.2009.Analisis dan Desain Sistem Informasi.Yogyakarta: Andi.

Jogiyanto. 2005. Analisis dan Desain Sistem Informasi. Yogyakarta: Penerbit Andi.

Kusrini. 2007. Konsep dan Aplikasi Sistem Pendukung Keputusan. Yogyakarta: Penerbit Andi.

Mallach, E.G. : Decision Support and Data Warehouse System. MsGraw Hill Higher Education, New York (2000).

M. Artanti Rim Saulina Manik (2012) "Penerapan Metode Weighted Product Dalam Sistem Pendukung Keputusan Seleksi Penerimaan Beras Untuk Masyarakat Miskin", Jurnal Teknologi Informasi Universitas Dian

Nuswantoro, Semarang. Shiddiq Fahriadi Seban (2013) : "Sistem pendukung keputusan penentuan lokasi kantor bank indonesia gorontalo menggunakan metode weighted product". Universitas Negeri Gorontalo, Gorontalo. 